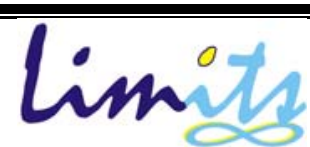

Limits: Journal of Mathematics and Its Applications

E-ISSN: 2579-8936

P-ISSN: $1829-605 \mathrm{X}$

Vol. 17, No. 1, Juli 2020, 9-18

DOI: http://dx.doi.org/10.12962/limits.v17i1.6752

\title{
Aliran Konveksi Campuran Magnetohidrodinamik yang Melewati Bola Bermagnet
}

\author{
Lutfi Mardianto $^{1 *}$, Basuki Widodo ${ }^{2}$, Dieky Adzkiya ${ }^{3}$ \\ ${ }^{1}$ Departemen Matematika Institut Teknologi Sumatera, Lampung Selatan \\ ${ }^{2,3}$ Departemen Matematika Institut Teknologi Sepuluh Nopember Surabaya Indonesia \\ e-mail: lutfi.mardianto@ma.itera.ac.id
}

Diajukan:9 April 2020, Diperbaiki: 22 Mei 2020, Diterima:23 Mei 2020

\begin{abstract}
Abstrak
Permasalahan yang dibahas pada paper ini adalah aliran konveksi campuran magnetohidrodinamik (MHD) tak tunak dari fluida Newtonian yang melalui bola bermagnet. Persamaan pembangun dimensional terdiri dari persamaan kontinuitas, persamaan momentum dan persamaan energi. Persamaan ini diubah ke bentuk non-dimensional menggunakan variabel non-dimensional. Selanjutnya, semua persamaan dianalisis dengan teori lapisan batas dan ditransformasikan ke bentuk persamaan non-similar. Persamaan ini diselesaikan secara numerik menggunakan metode beda hingga skema implisit. Profil kecepatan dan temperatur di permukaan bola bermagnet ditentukan oleh beberapa parameter seperti bilangan Prandtl (Pr), parameter magnetik $(\mathrm{M})$ dan parameter konveksi campuran $(\alpha)$. Gesekan kulit dan transfer panas dipelajari dan diinvestigasi selain kecepatan dan temperatur.
\end{abstract}

Kata Kunci: magnetohidrodinamik, konveksi campuran, bola bermagnet, skema implisit.

\begin{abstract}
The problem of unsteady magnetohydrodynamics (MHD) mixed convection of Newtonian fluid flow over a magnetic sphere is considered in this paper. Dimensional governing equations are constructed from continuity equation, momentum equation and energy equation. These governing equations are changed into non-dimensional one by using non-dimensional variables. Further, all equations are analyzed by boundary layer theory and transformed into similarity equation. These equations are solved numerically by using finite diference method implicit scheme. The velocity and temperature profiles along surface of a magnetic sphere are determined by variations of parameters such as Prandtl number (Pr), Magnetic parameter (M) and mixed convection parameter $(\alpha)$. The skin friction and the Nusselt number are studied and investigated.
\end{abstract} Keywords: magnetohydrodynamics, mixed convection, magnetic sphere, implicit scheme.

\section{Pendahuluan}

Magnetohidrodinamik merupakan suatu studi terhadap fenomena interaksi fluida terinduksi dan elektromagnetik. Studi tentang aliran ini sangat penting untuk beberapa penerapan seperti akselerator dan generator MHD, pendingin reaktor nuklir, dan pertumbuhan kristal. Kondisi ini membuat peneliti tertarik untuk mempelajarinya akhir-akhir ini. 
Beberapa peneliti telah melakukan studi terhadap magnetohidrodinamik. Nursalim, dkk. [1] mempelajari perilaku aliran fluida magnetohidrodinamik pada bola teriris di titik stagnasi $x=0$. Muhammad, dkk. [2] memaparkan pengaruh magnetohidrodinamik terhadap pengendalian aliran separasi.

Konveksi aliran fluida terjadi karena fluida dipengaruhi oleh gaya apung, gaya eksternal atau keduanya. Konveksi yang terdiri dari gaya apung dan gaya eksternal disebut konveksi campuran. Permasalahan tentang aliran fluida konveksi campuran telah dilakukan oleh beberapa peneliti. Kotouc, dkk. [3] menginvestigasi kehilangan axisymmetry pada aliran konveksi campuran melewati bola dipanaskan. Nazar, dkk. [4] mempelajari aliran konveksi campuran tunak melewati bola pejal dengan temperatur permukaan yang konstan dalam aliran yang terbantu maupun berlawanan.

Keberadaan medan magnet beserta adanya konveksi aliran fluida semakin gencar dipelajari. Molla, dkk. [5] mempertimbangkan aliran konveksi alami magnetohidrodinamik dengan keberadaan panas untuk mempelajari gesekan kulit dan transfer panas selain distribusi kecepatan dan temperatur. Prasad, dkk. [6] menganalisis pengaruh radiasi pada perilaku kecepatan temperatur fluida pada aliran konveksi alami atau bebas. Beg, dkk. [7] mempelajari konveksi bebas atau alami pada bola terhadap media berpori non-Darcian dengan keberadaan panas atau efek penyerapan. Chamkha, dkk. [8] menginvestigasi konveksi campuran magnetohidrodinamik pada titik stagnasi terdepan dari bola berputar dengan perbedaan temperatur permukaan. Widodo, dkk. [9] memaparkan efek dari bilangan Prandtl dan parameter magnetik pada konveksi paksa magnetohidrodinamik selain mempelajari aliran fluida magnetohidrodinamik dengan konveksi campuran yang melewati bola bermagnet terhadap profil kecepatan dan temperatur pada titik stagnasi terbawah [10].

Dalam paper ini, peneliti mempelajari gesekan kulit dan tranfer panas yang diakibatkan profil kecepatan dan temperatur dari aliran fluida magnetohidrodinamik konveksi campuran tak tunak yang melewati bola bermagnet. Masalah ini diselesaikan secara numerik dengan metode beda hingga skema implisit. Aliran yang terbantu dipilih sebagai konveksinya dengan bola bermagnet sebagai penghalang.

\section{Pemodelan Matematika}

Gambar 1 menunjukkan masalah fisik dalam penelitian ini. Fluida yang digunakan adalah fluida Newtonian yang mengalir ke atas dan berlawanan dengan gravitasi $g$. Aliran bebas disimbolkan sebagai $U_{\infty}$ dan temperatur pada aliran bebas disimbolkan sebagai $T_{\infty}$. Benda yang dipakai sebagai penghalang adalah bola bermagnet dengan radius $a$ dalam bidang berdimensi dua. 
Kekuatan medan magnet $B_{0}$ pada bola diterapkan pada komponen $-z$. Dalam penelitian ini, bilangan magnetik Reynolds diasumsikan kecil, tidak ada arus listrik sehingga medan listriknya nol. Koordinat $\bar{x}$ diukur titik stagnasi terbawah dengan arah berlawanan dengan jarum jam sementara koordinat $\bar{y}$ diukur dari garis normal menjauhi permukaan bola.

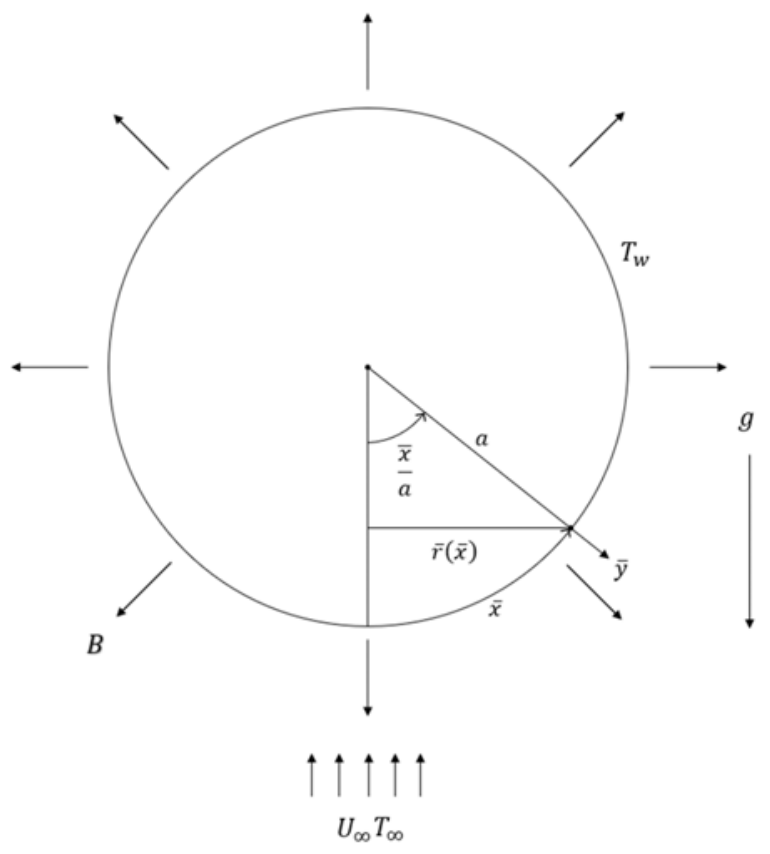

Gambar 1. Skema penelitian

Persamaan pembangun dimensional terdiri dari persamaan kontinuitas, persamaan momentum, dan persamaan energi yang ditulis sebagai berikut.

$$
\begin{gathered}
\frac{\partial \overline{r u}}{\partial \bar{x}}+\frac{\partial \overline{r v}}{\partial \bar{y}}=0 \\
\rho\left(\frac{\partial \bar{u}}{\partial \bar{t}}+\bar{u} \frac{\partial \bar{u}}{\partial \bar{x}}+\bar{u} \frac{\partial \bar{v}}{\partial \bar{y}}\right)=-\frac{\partial \bar{p}}{\partial \bar{x}}+\mu\left(\frac{\partial^{2} \bar{u}}{\partial \bar{x}^{2}}+\frac{\partial^{2} \bar{u}}{\partial \bar{y}^{2}}\right)+\sigma B_{0} \bar{u}+\rho g \beta\left(\bar{T}-T_{\infty}\right) \sin (\bar{x} / a) \\
\rho\left(\frac{\partial \bar{v}}{\partial \bar{t}}+\bar{v} \frac{\partial \bar{u}}{\partial \bar{x}}+\bar{v} \frac{\partial \bar{v}}{\partial \bar{y}}\right)=-\frac{\partial \bar{p}}{\partial \bar{y}}+\mu\left(\frac{\partial^{2} \bar{v}}{\partial \bar{x}^{2}}+\frac{\partial^{2} \bar{v}}{\partial \bar{y}^{2}}\right)+\sigma B_{0} \bar{v}-\rho g \beta\left(\bar{T}-T_{\infty}\right) \cos (\bar{x} / a) \\
\rho C_{p}\left(\frac{\partial \bar{T}}{\partial \bar{t}}+\bar{u} \frac{\partial \bar{T}}{\partial \bar{x}}+\bar{u} \frac{\partial \bar{T}}{\partial \bar{y}}\right)=k\left(\frac{\partial^{2} \bar{T}}{\partial \bar{x}^{2}}+\frac{\partial^{2} \bar{T}}{\partial \bar{y}^{2}}\right)
\end{gathered}
$$

dengan kondisi batas

$$
\begin{aligned}
\bar{t}<0: \bar{u} & =\bar{v}=0, \bar{T}=T_{\infty} \text { for any } \bar{x}, \bar{y} \\
\bar{t} \geq 0: \bar{u} & =\bar{v}=0, \bar{T}=T_{w} \text { for } \bar{y}=0 \\
\bar{u} & =\overline{u_{e}}, \bar{T}=T_{\infty} \text { as } \bar{y} \rightarrow \infty
\end{aligned}
$$


dimana $\rho$ densitas fluida, $\mu$ viskositas fluida, $g$ gravitasi, $\beta$ koefisien ekspansi panas, $C_{p}$ panas spesifik, dan $k$ fluks panas. Selanjutnya, nilai $r$ didefinisikan sebagai $\bar{r}(\bar{x})=a \sin (\bar{x} / a)$, dan nilai arus bebas $\bar{u}_{e}$ didefinisikan sebagai $\bar{u}_{e}=(3 / 2) \sin (\bar{x} / a)$ untuk kasus pada bola.

Selanjutnya, variabel non-dimensional digunakan untuk mentransformasi Persamaan (1) - (4) menjadi persamaan non-dimensional seperti berikut ini.

$$
\begin{gathered}
x=\frac{\bar{x}}{a}, \quad y=\operatorname{Re}^{\frac{1}{2} \frac{\bar{y}}{a}}, \quad u=\frac{\bar{u}}{U_{\infty}}, \quad v=\operatorname{Re}^{\frac{1}{2}} \frac{\bar{v}}{U_{\infty}}, \\
t=\frac{U_{\infty} \bar{t}}{a}, \quad p=\frac{\bar{p}}{\rho U_{\infty}}, \quad T=\frac{\bar{T}-T_{\infty}}{T_{w}-T_{\infty}}, \quad r=\frac{\bar{r}(\bar{x})}{a}
\end{gathered}
$$

Teori lapisan batas diterapkan pada sistem persamaan pembangun nondimensional sehingga sistem tereduksi menjadi

$$
\begin{gathered}
\frac{\partial r u}{\partial x}+\frac{\partial r v}{\partial y}=0 \\
\frac{\partial u}{\partial t}+u \frac{\partial u}{\partial x}+u \frac{\partial v}{\partial y}=u_{e} \frac{\partial u_{e}}{\partial x}+\frac{\partial^{2} u}{\partial y^{2}}+M\left(u-u_{e}\right)-\alpha T \sin x \\
\frac{\partial T}{\partial t}+u \frac{\partial T}{\partial x}+v \frac{\partial T}{\partial y}=\frac{1}{\operatorname{Pr}} \frac{\partial^{2} T}{\partial y^{2}}
\end{gathered}
$$

dengan kondisi batas untuk persamaan pembangun non-dimensional seperti berikut ini.

$$
\begin{aligned}
t<0: u & =0, T=0 \text { for any } x, y \\
t \geq 0: u & =v=0, T=1 \text { for } y=0 \\
u & =u_{e}, T=0 \text { as } y \rightarrow \infty
\end{aligned}
$$

Parameter non-dimensional yang muncul dalam sistem didefinisikan sebagai

$$
\operatorname{Re}=\frac{U_{\infty} a}{v}, \operatorname{Pr}=\frac{v \rho C_{P}}{k}, \quad M=\frac{\sigma B_{0}^{2} a}{\rho U_{\infty}}, \quad \alpha=\frac{\mathrm{Gr}}{\operatorname{Re}^{2}}, \quad \operatorname{Gr}=\frac{g \beta\left(T_{W}-T_{\infty}\right) a^{3}}{v}
$$

dimana $\operatorname{Pr}$ adalah bilangan Prandtl, $M$ adalah parameter magnetik dan $\alpha$ adalah parameter konveksi campuran.

Pada aliran dua dimensi, kecepatan pada komponen $-x$ dan $-y$ dapat dinyatakan sebagai stream function seperti berikut ini

$$
u=\frac{1}{r} \frac{\partial \psi}{\partial y} \quad \text { and } \quad v=-\frac{1}{r} \frac{\partial \psi}{\partial x}
$$

Dengan substitusi Persamaan (8) ke Persamaan (5) dan (6), maka

$$
\frac{1}{r} \frac{\partial^{2} \psi}{\partial t \partial y}-\frac{1}{r^{3}} \frac{\partial r}{\partial x}\left(\frac{\partial \psi}{\partial y}\right)^{2}+\frac{1}{r^{2}} \frac{\partial \psi}{\partial y} \frac{\partial^{2} \psi}{\partial x \partial y}-\frac{1}{r^{2}} \frac{\partial \psi}{\partial x} \frac{\partial^{2} \psi}{\partial y^{2}}=u_{e} \frac{\partial u_{e}}{\partial x}+\frac{1}{r} \frac{\partial^{3} \psi}{\partial y^{3}}+M\left(\frac{1}{r} \frac{\partial \psi}{\partial y}-1\right)+\alpha T \sin x
$$




$$
\frac{\partial T}{\partial t}+\frac{1}{r} \frac{\partial \psi}{\partial y} \frac{\partial T}{\partial x}-\frac{1}{r} \frac{\partial \psi}{\partial x} \frac{\partial T}{\partial y}=\frac{1}{\operatorname{Pr}} \frac{\partial^{2} T}{\partial y^{2}}
$$

dengan kondisi batas

$$
\begin{aligned}
t<0: \psi=\frac{\partial \psi}{\partial y} & =0, T=0 \text { for any } x, y \\
t \geq 0: \psi=\frac{\partial \psi}{\partial y} & =0, T=1 \text { for } y=0 \\
\frac{\partial \psi}{\partial y} & =r u_{e}, T=0 \text { as } y \rightarrow \infty
\end{aligned}
$$

Untuk memperoleh solusi pada kasus small time $\left(t \leq t^{*}\right)$, variabel non-similaritas yang digunakan pada sistem persamaan pembangun adalah

$$
\psi=t^{1 / 2} u_{e}(x) r(x) f(x, \eta, t), \quad \eta=\frac{y}{t^{1 / 2}}, \quad T=s(x, \eta, t)
$$

Dengan substitusi variabel non-similaritas di atas ke Persamaan (9) dan (10), sistem persamaan pembangun untuk kasus small time menjadi

$$
\begin{aligned}
& \frac{\partial^{3} f}{\partial \eta^{3}}+\frac{\eta}{2} \frac{\partial^{2} f}{\partial \eta^{2}}+t \frac{\partial u_{e}}{\partial x}\left(1-\left(\frac{\partial f}{\partial \eta}\right)^{2}+f \frac{\partial^{2} f}{\partial \eta^{2}}\right)=\frac{\partial^{2} f}{\partial t \partial \eta}+t u_{e}\left(\frac{\partial^{2} f}{\partial x \partial \eta} \frac{\partial f}{\partial \eta}-\frac{\partial f}{\partial x} \frac{\partial^{2} f}{\partial \eta^{2}}-\frac{f}{r} \frac{\partial r}{\partial x} \frac{\partial^{2} f}{\partial \eta^{2}}\right) \\
& -t M\left(\frac{\partial f}{\partial \eta}-1\right)-\alpha \frac{t s}{u_{e}} \sin x \\
& \frac{\partial^{2} s}{\partial \eta^{2}}+\operatorname{Pr} \frac{\eta}{2} \frac{\partial s}{\partial \eta}+\operatorname{Pr} t f \frac{\partial u_{e}}{\partial x} \frac{\partial s}{\partial \eta}=\operatorname{Pr} t\left(\frac{\partial s}{\partial t}+u_{e}\left(\frac{\partial s}{\partial x} \frac{\partial f}{\partial \eta}-\frac{\partial f}{\partial x} \frac{\partial s}{\partial \eta}-\frac{f}{r} \frac{\partial r}{\partial x} \frac{\partial s}{\partial \eta}\right)\right)
\end{aligned}
$$

dengan kondisi batas seperti di bawah ini

$$
\begin{aligned}
& t<0: f= \frac{\partial f}{\partial \eta}=0, s=1 \text { for any } x, \eta \\
& t \geq 0: f= \frac{\partial f}{\partial \eta}=0, s=0 \text { for } \eta=0 \\
& \frac{\partial f}{\partial \eta}=1, T=0 \text { as } \eta \rightarrow \infty
\end{aligned}
$$

Untuk kasus large time $\left(t>t^{*}\right)$, variable non-similaritas didefinisikan sebagai

$$
\psi=u_{e}(x) r(x) F(x, Y, t), \quad y=Y, \quad T=S(x, Y, t)
$$

Variabel non-similaritas di atas disubstitusikan ke Persamaan (9) dan (10) sehingga

$$
\begin{aligned}
& \frac{\partial^{3} F}{\partial Y^{3}}+\frac{\partial u_{e}}{\partial x}\left(1-\left(\frac{\partial F}{\partial Y}\right)^{2}+F \frac{\partial^{2} F}{\partial Y^{2}}\right)=\frac{\partial^{2} F}{\partial t \partial Y}+u_{e}\left(\frac{\partial^{2} F}{\partial x \partial Y} \frac{\partial F}{\partial Y}-\frac{\partial F}{\partial x} \frac{\partial^{2} F}{\partial Y^{2}}-\frac{F}{r} \frac{\partial r}{\partial x} \frac{\partial^{2} F}{\partial Y^{2}}\right)-M\left(\frac{\partial F}{\partial Y}-1\right)-\alpha \frac{S}{u_{e}} \sin x \\
& \frac{\partial^{2} S}{\partial Y^{2}}+\operatorname{Pr} F \frac{\partial u_{e}}{\partial x} \frac{\partial S}{\partial Y}=\operatorname{Pr}\left(\frac{\partial S}{\partial t}+u_{e}\left(\frac{\partial S}{\partial x} \frac{\partial F}{\partial Y}-\frac{\partial F}{\partial x} \frac{\partial S}{\partial Y}-\frac{F}{r} \frac{\partial r}{\partial x} \frac{\partial S}{\partial Y}\right)\right)
\end{aligned}
$$


dengan kondisi batas

$$
\begin{aligned}
& F=\frac{\partial F}{\partial Y}=0, T=1 \text { for } Y=0 \\
& F=\frac{\partial F}{\partial F}=1, T=0 \text { as } Y \rightarrow \infty
\end{aligned}
$$

\section{Hasil dan Pembahasan}

Dalam penelitian ini, pengaruh bermacam-macam parameter seperti parameter magnetik $M$, bilangan Prandtl $\operatorname{Pr}$ dan parameter konveksi campuran $\alpha$ terhadap kecepatan, temperatur, gesekan kulit dan transfer panas dipelajari. Program dibuat menggunakan Matlab. Grid yang digunakan dalam simulasi adalah $d x=5^{\circ}$ dan $d \eta=0,1$ dengan partisi $n x=36$ dan $n \eta=60$.

Parameter magnetik merepresentasikan keberadaan gaya Lorentz. Gaya magnetik yang semakin meningkat, berakibat pada gaya Lorentz yang meningkat pula. Hal ini berakibat pada kecepatan fluida berkurang seperti pada Gambar 2a. Menurunnya kecepatan fluida tidak hanya terjadi pada titik stagnasi, tetapi juga di sepanjang permukaan bilangan magnetik seperti pada Gambar 2b.

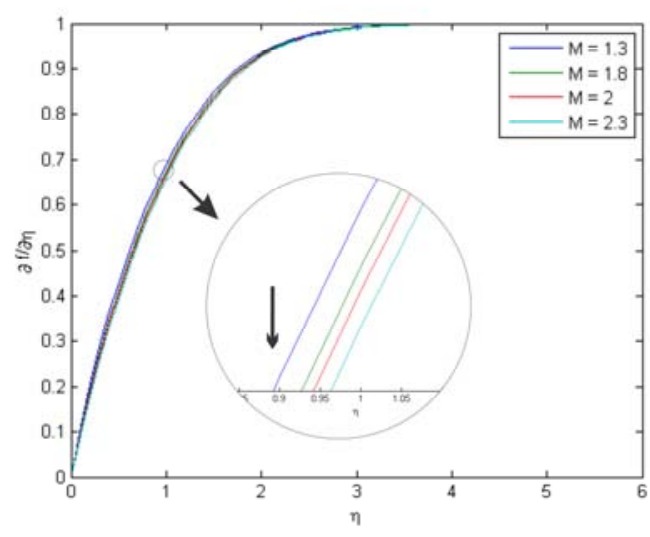

(a)

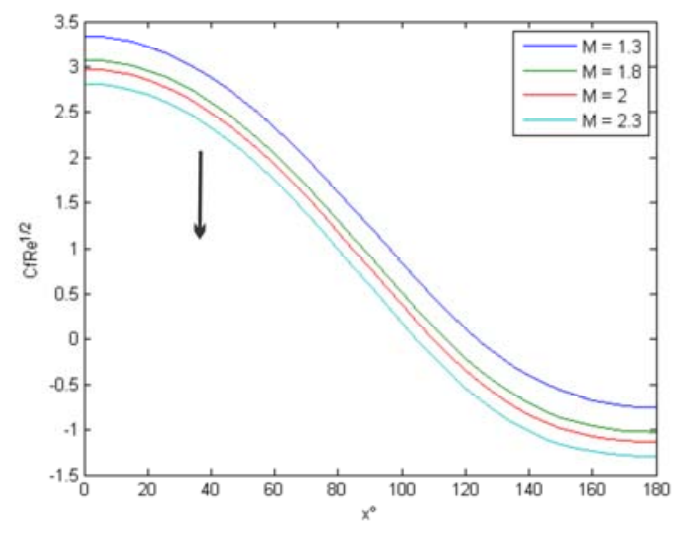

(b)

Gambar 2. (a) Profil kecepatan pada titik stagnasi terendah dan (b) profil gesekan kulit dengan parameter magnetik yang bermacam-macam dengan $\operatorname{Pr}=1$ dan $\alpha=1$.

Dalam Gambar 3a, temperatur fluida menurun ketika parameter magnetik meningkat. Temperatur menurun karena penurunan energi internal fluida. Kenaikan bilangan magnetik berakibat pada menurunnya kecepatan fluida sehingga temperatur fluida menurun.

Transfer panas pada fluida ditunjukkan oleh bilangan Nusselt. Bilangan Nusselt yang tinggi berarti transfer panas dari bola terhadap fluida berlangsung lambat. Bilangan Nusselt meningkat ketika parameter magnetik meningkat seperti pada Gambar 3b. Kenaikan parameter magnetik 
berakibat pada menurunnya kecepatan fluida pada permukaan bola sehingga temperatur fluida menurun. Akibatnya, bilangan Nusselt meningkat.

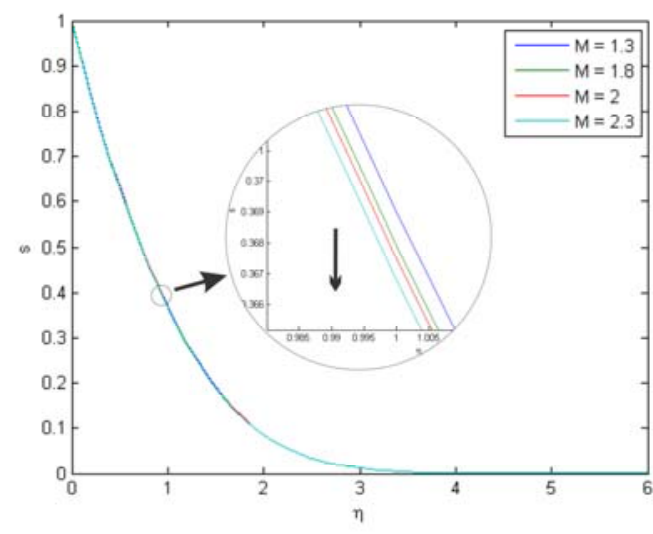

(a)

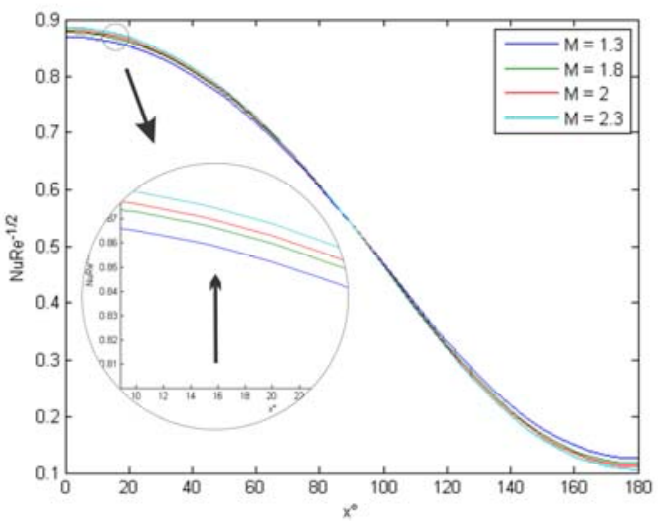

(b)

Gambar 3. (a) Profil temperatur pada titik stagnasi terendah dan (b) profil bilangan Nusselt dengan parameter magnetik yang bermacam-macam dengan $\operatorname{Pr}=1$ dan $\alpha=1$.

Bilangan Prandtl didefinisikan sebagai rasio antara difusivitas momentum dan difusivitas panas. Dari Gambar 4a, kenaikan bilangan Prandtl berpengaruh pada menurunnya kecepatan fluida. Tingginya difusivitas momentum membuat aliran fluida lambat. Hal ini nampak pada menurunnya gesekan kulit seperti pada Gambar 4b.

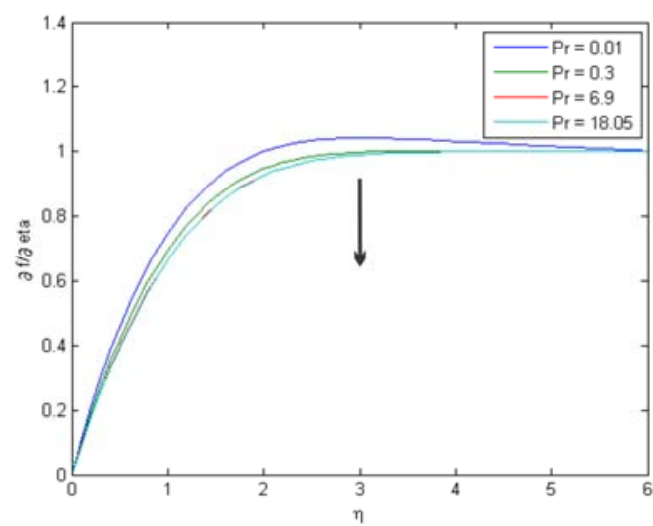

(a)

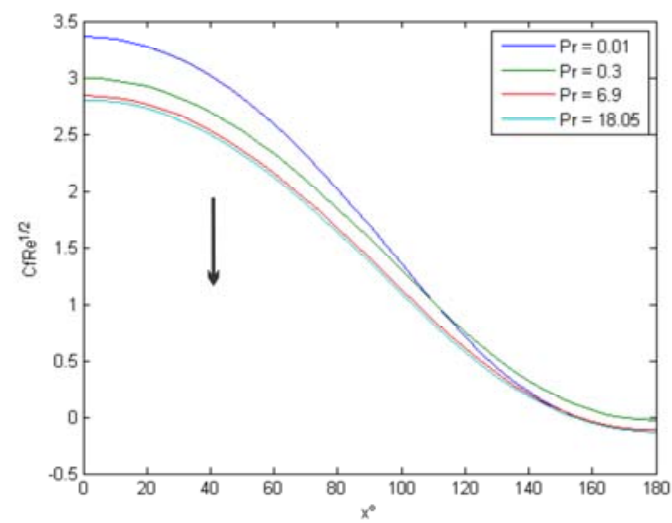

(b)

Gambar 4. (a) Profil kecepatan pada titik stagnasi terendah dan (b) profil gesekan kulit dengan bilangan Prandtl yang bermacam-macam dengan $M=1$ dan $\alpha=1$.

Gambar 5a menunjukkan bahwa ketika bilangan Prandtl meningkat, temperatur fluida menurun. Kenaikan bilangan Prandtl berpengaruh pada menurunnya difusivitas panas. Akibatnya, temperatur fluida menurun. Terdapat perbedaan antara bilangan Prandtl $0<\operatorname{Pr}<1$ dan $\operatorname{Pr}>1$. 
Bilangan Prandtl $0<\operatorname{Pr}<1$ berarti nilai difusivitas panas dominan sehingga temperatur fluida tinggi, tetapi bilangan Prandtl $\operatorname{Pr}>1$ berarti momentum difusivitas momentum lebih dominan. Akibatnya, kenaikan bilangan Prandtl pada $\operatorname{Pr}>1$ tidak merubah secara signifikan terhadap penurunan temperatur fluida.

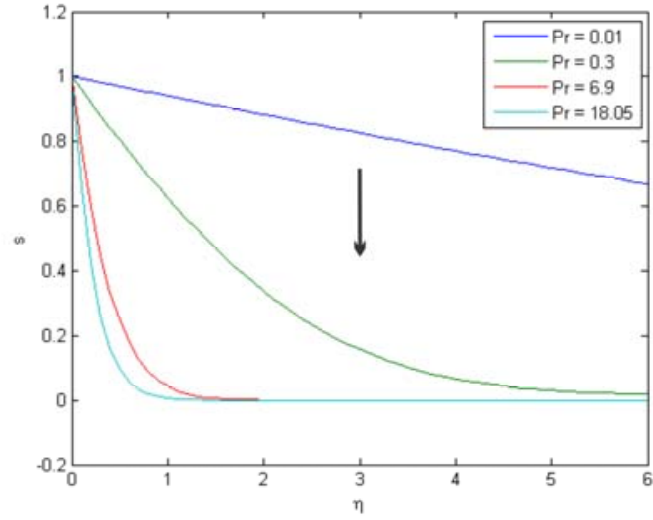

(a)

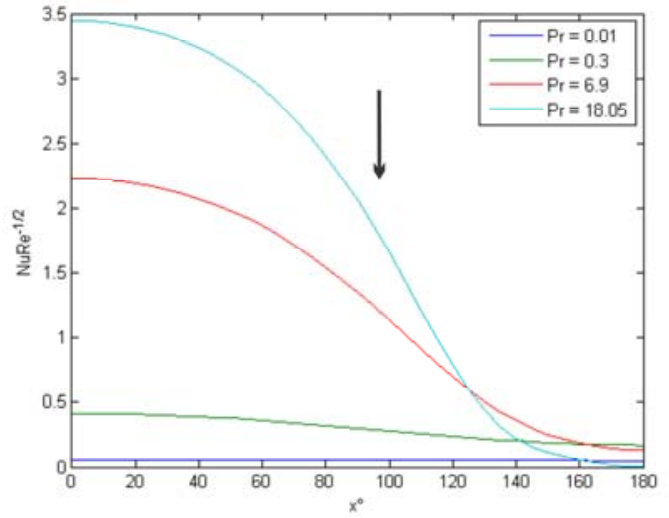

(b)

Gambar 5. (a) Profil temperatur pada titik stagnasi terendah dan (b) profil bilangan Nusselt dengan bilangan Prandtl yang bermacam-macam dengan $M=1$ dan $\alpha=1$.

Seperti yang telah dideskripsikan sebelumnya, kenaikan bilangan Prandtl berpengaruh pada penurunan temperatur. Akibatnya, bilangan Nusselt meningkat seperti pada Gambar 5b. Bilangan Nusselt yang tinggi berarti tranfer panas berlangsung lambat.

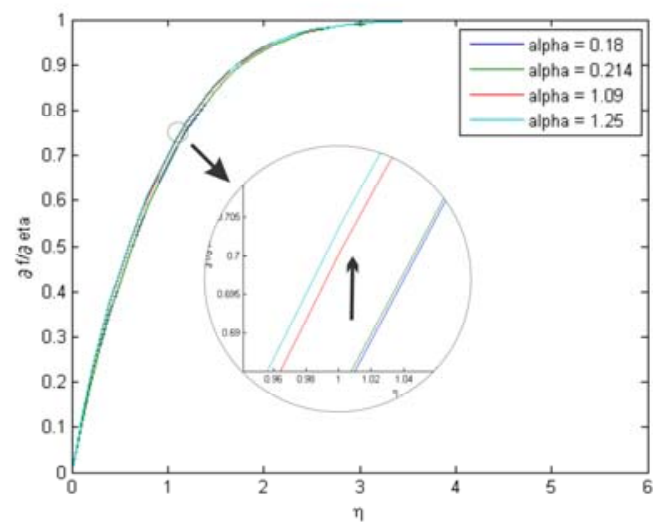

(a)

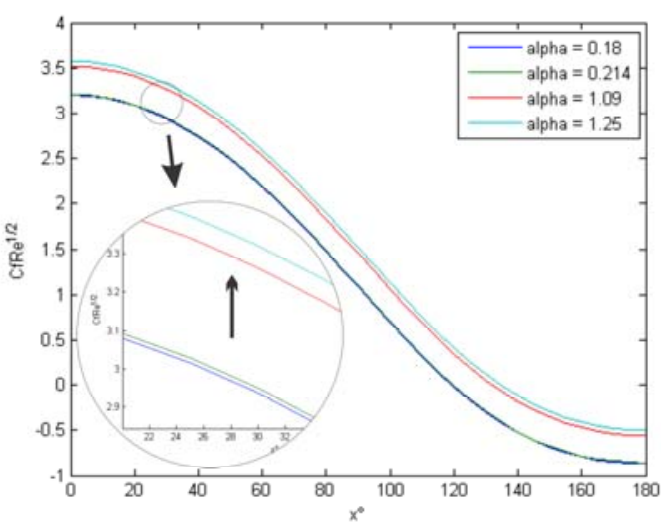

(b)

Gambar 6. (a) Profil kecepatan pada titik stagnasi terendah dan (b) profil gesekan kulit dengan parameter konveksi campuran yang bermacam-macam dengan $M=1$ dan $\operatorname{Pr}=1$.

Parameter konveksi campuran menunjukkan keberadaan gaya apung dibandingkan dengan gaya eksternal pada aliran fluida. Konveksi alami atau bebas dominan ketika parameter konveksi 
campuran berada pada rentang $0<\alpha<1$, sedangkan konveksi paksa dominan ketika parameter konveksi campuran berada pada rentang $\alpha>1$. Gambar 6a menggambarkan kecepatan fluida meningkat ketika parameter konveksi meningkat. Kenaikan parameter konveksi campuran berpengaruh pada penurunan densitas fluida. Akibatnya, fluida mengalir dengan cepat. Peningkatan parameter konveksi campuran berpengaruh pada peningkatan gesekan kulit seperti pada Gambar 6b. Peningkatan parameter konveksi campuran berpengaruh pada peningkatan kecepatan fluida. Akibatnya, gesekan kulit juga meningkat.
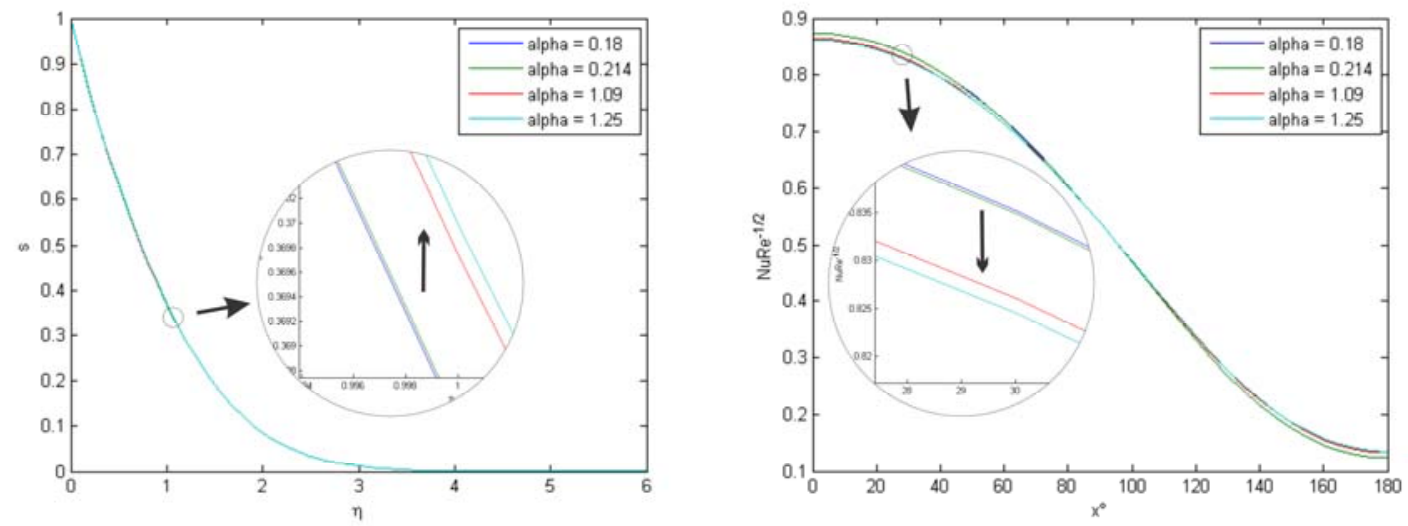

Gambar 7. (a) Profil temperatur pada titik stagnasi terendah dan (b) profil bilangan Nusselt dengan parameter konveksi campuran yang bermacam-macam dengan $M=1$ dan $\operatorname{Pr}=1$.

Kenaikan parameter konveksi campuran berpengaruh pada kenaikan temperatur seperti pada Gambar 7a. Kenaikan bilangan berpengaruh pada kenaikan kecepatan fluida sehingga energi internal meningkat. Akibatnya, temperatur fluida juga meningkat. Temperatur fluida berhubungan dengan bilangan Nusselt. Ketika temperatur fluida meningkat, bilangan Nusselt menurun seperti pada Gambar 7b yang berarti transfer panas berlangsung cepat.

\section{Simpulan}

Dalam penelitian ini, aliran konveksi campuran magnetohidrodinamik melewati bola bermagnet dipelajari. Pengaruh parameter non-dimensional seperti prameter magnetik, bilangan Prandtl dan parameter konveksi campuran juga dipelajari. Kenaikan parameter magnetik berakibat pada menurunnya kecepatan, temperatur dan gesekan kulit, tetapi bilangan Nusselt meningkat. Kenaikan bilangan Prandtl berpengaruh pada menurunnya kecepatan, temperatur dan gesekan kulit, tetapi bilangan Nusselt meningkat. Kenaikan parameter konveksi campuran mengakibatkan meningkatnya kecepatan, temperatur dan gesekan kulit, tetapi bilangan Nusselt menurun. 


\section{Daftar Pustaka}

[1] Nursalim, R., Widodo, B., dan Imron, C., Magnetohydrodynamics of unsteady viscous fluid on boundary layer past a sliced sphere. Journal of Physics: Conference Series. Vol. 893. No. 1. IOP Publishing, 2017.

[2] Mohammad, N. F., Kasim, A. R. M., Ali, A., \& Shafie, S., Effect of MHD on unsteady boundary layer flow past a sphere. Proceedings of The Annual International Conference, Syiah Kuala University-Life Sciences \& Engineering Chapter. Vol. 3. No. 2. (2013).

[3] Kotouc, M., Bouchet, G., dan Dusek, J., Loss of axisymmetry in the mixed convection, assisting flow past a heated sphere, Vol. 51 (2008): 2686-2700.

[4] Nazar, R., Amin, N., dan Pop, I., On the mixed convection boundary layer flow about a solid sphere with constant surface temperature, The Arabian journal for science and engineering, Vol. 27 (2002), 117-135.

[5] Molla, M. M., Taher, M. A., Chowdhury, M. M. K., dan Hossain, M. A., Magnetohydrodynamic natural convection flow on a sphere in presence of heat generation, Nonlinear analysis: modelling and control, Vol. 10 (2005), 349-363.

[6] Prasad, V. R., Vasu, B. A. B. O., Bég, O. A., \& Parshad, R. D., Thermal radiation effects on magnetohydrodynamic free convection heat and mass transfer from a sphere in a variable porosity regime. Communications in Nonlinear Science and Numerical Simulation, Vol. 17 (2012), 654-671.

[7] Beg, O. A., Zueco, J., Bhargava, R., dan Takhar, H. S., Magnetohydrodynamic convection flow from a sphere to a non-Darcian porous medium with heat generation or absorption effects: network simulation, International Journal of Thermal Sciences, Vol. 48 (2009), 913-921.

[8] Chamkha, A. J., dan Ahmed, S. E., Unsteady MHD heat and mass transfer by mixed convection flow in the forward stagnation region of a rotating sphere at different wall conditions, Chemical engineering communications, Vol. 199 (2012), 122-141.

[9] Widodo, B., Khalimah, D. A., Zainal, F. D. S., dan Imron, C., The effect of Prandtl number and magnetic parameter on forced convection unsteady magnetohydrodynamics boundary layer flow of a viscous fluid past a sphere, International journal of advances in science, engineering and technology, Vol. 4 (2017), 75-78.

[10] Widodo, B., Mardianto, L., Adzkiya, D., Numerical investigation on magnetohydrodynamics mixed convection flow past a magnetic sphere, Journal of Physics: Conference Series, Vol. 1153, No. 1. IOP Publishing, 2019. 